\title{
ANALYSIS OF THE STABILITY OF WOODY PLANT SPECIES OF URBAN ECOSYSTEM OF ZHYTOMYR
}

\author{
Herasymchuk O.L., Korbut M.B., Kotsiuba I.H. \\ Zhytomyr Polytechnic State University \\ 103, Chudnivska str., 10005, Zhytomyr \\ olena_1409@ukr.net, korbutmari81@gmail.com,chaszmin30@gmail.com
}

\begin{abstract}
The article examines the features of woody plant species, their adaptation to the action of stress abiotic factors. The urban environment has a negative impact on the living conditions of plants, which is noted for their phytomeliorative and decorative role. Such conditions, although they do not cause massive visual damage, but speed up and shorten the life cycle, cause premature weakening, aging and loss of species phytodiversity of planting. The paper investigates the stability of woody species in an urbanized ecosystem on the example of the city of Zhytomyr. The authors study the environmental and phytomeliorative role of plantings in the conditions of technogenic load, in particular, road pollution. The main types of woody plants that predominate in the city's plantings are established. Plants of the Tilia L. genus prevailed within species diversity; their representatives are effective woody species in terms of resistance to gas and dust emissions, $\mathrm{SO}_{2}$ absorption, and dust absorption. However, the aesthetic appearance of Linden trees is worsened due to an increase in phytopathological load on the general condition and vital activity of plants owing to incorrect tree pruning. It is shown that in conditions of deep anti-aging pruning, the resistance of plants to the main anthropogenic pollutants decreases, while the number of plants affected by diseases and pests increases. It was found that in urban plantations, the effectiveness of the use of the studied plant species increases with plant age raising and with the use of sanitary trimming. The studied plant species are sensitive to anthropogenic load, therefore, they are effective as indicators of the state of the environment.

Creation of protective plantings is most expedient on the basis of studying of ecological plasticity of species of woody plants. The research results allow us to reveal new aspects of the use of woody plant species in urban landscaping. Key words: stability, adaptation, woody plant species, technogenic pollution, chlorosis, necrosis.
\end{abstract}

Аналіз стійкості деревних видів рослин урбоекосистеми м. Житомира. Герасимчук О.Л., Корбут М.Б., Коцюба І.Г.

У статті досліджено особливості деревних видів рослин, їхню адаптацію до дії стресових абіотичних факторів. Урбанізоване середовище має негативний вплив на життєвий стан рослин, що відзначається на їхній фітомеліоративній і декоративній ролі. Такі умови хоч і не спричиняють масових візуальних ушкоджень, але пришвидшують і скорочують життєвий цикл, зумовлюють передчасне ослаблення, старіння та втрати видового фіторізноманіття насаджень. Проаналізовано стійкість деревних порід в умовах урбанізованої екосистеми на прикладі міста Житомира. Вивчено середовищеутворювальну й фітомеліоративну роль насаджень в умовах техногенного навантаження, зокрема автотранспортного забруднення. Встановлено основні види деревних рослин, що переважають у насадженнях міста. За видовим різноманіттям переважали рослини роду Tilia L., представники якого $є$ ефективними деревними породами за показниками стійкості до газопилових викидів, поглинання $\mathrm{SO}_{2}$ i поглинання пилу. Однак естетичний вигляд дерев липи серцелистої погіршений у зв'язку зі збільшенням фітопатологічного навантаження на загальний стан і життедіяльність рослин внаслідок некоректного кронування. Показано, що в умовах глибокого омолоджувального обрізування стійкість рослин до головних антропогенних забруднювачів знижується, водночас зростає кількість рослин, уражених хворобами й шкідниками. 3'ясовано, що в умовах міських насаджень ефективність використання досліджених видів рослин зростає зі збільшенням віку рослин і під час застосування санітарного обрізання. Досліджувані види рослин $є$ чутливими до антропогенного навантаження, отже ефективні як індикатори стану довкілля.

Створення захисних насаджень найдоцільніше на основі вивчення екологічної пластичності видів деревних рослин. Результати досліджень дозволяють розкрити нові аспекти використання деревних видів рослин в озелененні урбанізованих територій. Ключові слова: стійкість, адаптація, деревні види рослин, техногенне забруднення, хлороз, некроз.

Problem statement. Urban development of territories leads to the creation of new negative climatic conditions, and at the same time leads to a decrease in the functioning of urban tree plantations. At the same time, green spaces play an important sanitary and hygienic role, in particular in maintaining a constant air composition. It is the vegetation that makes the urban ecosystem a full-fledged ecosystem, and the presence of a network of green spaces in the city becomes a precondition for human survival.

However, not all types of woody plants have the same ability to adapt to the dynamics of a constant increase in anthropogenic load. There is a need to study the resistance of woody species to environmental pollution.
Topicality. Significant changes in climatic conditions are undoubtedly associated with the growth of the share of urbanized areas. A powerful natural factor to counteract the negative effects of urbanization and man-made pollution is woody species of plants that are actively used in greenery. At the same time, urbanic factors create a significant load on the life span of plants. This is especially acute in conditions of dense urban development and a constant increase in the number of road transport.

Analysis of recent research and publications. Now researchers pay considerable attention to the study of the role of green spaces in the optimization of anthropogenically transformed territories (H.H. Derevianska) [1]. S.O. Volodarets, O.Z. Hlukhov studied in their 
works the issues of phytoncid activity of woody plants in an urbanized environment $[2 ; 3]$. The dust-retaining ability of layered wood plates was studied by M.V. Nemchenko, T.F. Stelmakhova [4; 5].

Connection of the authors' contribution with important scientific and practical tasks. The main pollutants of atmospheric air in the city are road transport, the number of which increases annually, and various types of production. The compounds of sulfur and nitrogen are the most dangerous for plant, and cause lesions of the assimilation apparatus, manifested in the form of necrosis and chlorosis of different types. In addition, the action of toxic substances can be manifested in a decrease in the intensity of plant life and productivity, without the appearance of external signs.

The influence of xenobiotics on the condition of tree species of plants has been considered in the works of domestic and foreign researchers: P.S. Hnativ, K.P. Wyche, P. Harley [6-8].

As Yu.H. Prysedskyi noted, damage to plants by pollutants depends on the effective dose and has an expotential character [9].

The article is devoted to highlighting previously unsolved parts of the common problem. The influence of pollutants on woody plant species was studied, mainly related to the action of industrial pollutants, while the main environmental pollutant in the city of Zhytomyr is motor transport, the number of which is increasing. The issue of air pollution by vehicles in dense buildings, when houses are located close to the highway is underexplored. At the same time, the insufficient number of parking lots factors into increasing the number of vehicles that are parked on the road, which raises the number of traffic jams, and therefore creates an additional load on green plants.

The aim of our research is to establish the dependence of damage to woody species of plants on the level of congestion of streets by road transport.

The main material. Studies were carried out in the urban ecosystem of Zhytomyr, which is located within two soil-climatic zones i.e. Polissia zone in the northern part of the region and forest-steppe in the southern part.

Analysis of indicators of soil cover showed that green space grows under conditions of mostly weakly acidic and neutral $(\mathrm{pH}=5,6-7,3)$ soil reaction and low humus content $(1,15-2,58 \%)$. In general, urban soil is overcompacted (volume weight - 0,35-0,44 $\mathrm{g} / \mathrm{cm}^{3}$ ). Soils of squares and streets are characterized by even greater density (volume weight $-1,63-1,83 \mathrm{~g} / \mathrm{cm}^{3}$ ). In urban terrain there is a violation of the accumulation, distribution, microbial synthesis, humification and mineralization of primary organic matter. However, most researchers argue that for tree species, the quality of soil cover plays an important role only at a young age. Mature forms are characterized by a well-developed powerful root system, so soil quality indicators play less significant role. Indicators of air quality are more sub- stantial for wood species of middle and mature age are. In urbanized areas, the quality of the air environment is at a low level, which is primarily due to the increase in the number of road transport.

The streets of the city according to the level of traffic load were divided into five groups: clean air, relatively clean, polluted, heavily polluted and too heavily polluted. The most polluted areas are Kyivska and Velyka Berdychivska streets, as well as the city center.

As part of the dendroflora of Zhytomyr, among the protective plantings the following representatives of the families are dominated: Tilia (32\%): small-leaved linden (Tilia cordata Mill.), large-leaved linden (Tilia platyphyllos Scop.), Acer (25\%): Norway maple (Acer platanoidesL.), ash-leaved maple (Acer negundoL), Betulaceae (17\%): European white birch (Betula pendula Roth), Salicaceae Salicaceae (9\%): black poplar (Populus nigra L.), pyramid poplar (Populus pyramidalis Borkh.), white willow (Salix Alba L.), Hippocastanaceae (14\%) - horse chestnut (Aesculus hippocastanum L.), there are 2 families, 3 species of coniferous trees, namely the Cupressaceae family - Western thuja (thuja occidentalis L.) $4 \%$ of the total and the Pinaceae family - blue spruce (Picea epungens), common pine (Pinus sylvestrisL.).

The objects of research were woody species of horse chestnut (Aesculus hippocastanum L.), small-leaved linden (Tilia cordata Mill.), Norway maple (Acer platanoides), which are the main species represented in the landscaping of the city.

Analysis of the types of damage to the leaf of the main species of woody plants presented in landscaping of Zhytomyr showed that the most common types of damage are: necrosis $15 \%$, chlorosis $18 \%$, point and edge pigmentation $7 \%$, as well as damage to infestants, in particular tinder mushrooms $9 \%$. The most resistant is the Norway maple, while the horse chestnut was the least resistant to the main types of lesions. Small-leaved linden, which is the predominant species of woody plants in the landscaping of the streets of the city showed an average level of resistance to the main types of lesions.

Considering the fact that street plantings of Zhytomyr are represented mainly by species of the TiliaL. genus, which is about $32 \%$ of the total number of species, a more detailed study of the status of representatives of this genus was carried out.

The aesthetic appearance of the small-leaved linden trees degraded due to increase of phytopathological load on the overall status and life of the plant due to incorrect cutting. On street plantings the majority of plants is in unsatisfactory condition: from 329 examined individuals only $24 \%$ of trees are healthy (1-2 points) with well-developed crowns; $62 \%$ of studied trees with signs of diseases (3-4 points); 14\% of trees are in strongly oppressed or dying condition (5-6 points). Among the uncut trees of small-leaved linden on the Prospekt Vyzvolennia street the distribution according to phy- 
tosanitary conditions is as follows: healthy, well-developed trees $-76 \%$ (1-2 points), with minor signs of disease $-18 \%$ (3-4 points); dying - 6\% (5-6 points). Necrosis of leaves and drying of branches was the most common in non-crowns of linden trees, which is associated with an increased content of sodium salts in the wells of street plantations and high anthropogenic air and soil pollution along roads, near which experimental specimens grow.

Conclusions. It is established that deep rejuvenating pruning of linden trees in Zhytomyr has a negative impact on the vital condition of trees, affects their decorative effect, accelerates the aging process and reduces the average life expectancy. Trees of the Tilia L. genus, which succumbed to deep pruning of the crown, are most often affected by true tinder (Fomes fomentarius) and scaly tinder (Polyporus squamosus Huds.Fr.).
In general, linden trees are less resistant to pathogens that affect weakened plants after rejuvenating pruning. Non-crown representatives of the Tilia L. genus in street plantings are promising and fully perform phytomeliorative and protective functions.

It was found that in the conditions of Zhytomyr, the most stable species is the Norway maple. However, this species is characterized by a large growth force and therefore it is rarely used for landscaping. Smallleaved linden, which has shown average resistance to damage when limited tree pruning is a promising way that fully performs its protective functions.

Prospects for using the research results. The research made it possible to identify the most promising types of woody plants that are suitable for use in landscape greenery of new urban residential districts. As well as to establish long-term care for existing plantings.

\section{Bibliography}

1. Derevianska H.H. Urban flora of the Donetsk - Makiivka : extended abstract of Candidate of Biology Dissertation : 03.00.05 "Botanics". Yalta, 2014. 24 p.

2. Volodarets S.O. Phytoncid activity in connection with the content of chlorophylls in the leaves of woody plants in an urbanized environment. Industrial botany. 2012. No. 12. P. 167-171.

3. Hlukhov A.Z., Volodarets S.O. Phytoncidic activity of woody plants in an urbanized environment (exemplified by the city of Donetsk). The news of Samara scientific center of the Russian Academy of Sciences. 2013. Vol. 15. No. 3 (7). P. $2122-2125$.

4. Nemchenko M.V. Dust-holding capacity of the leaves of Catalpa bignonioide Walt. and Catalpa speciosa Ward trees. in urban technogenic growth conditions. Zaporizhzhia : ZNU, 2008. Issue 13. No. 2. P. 29-39.

5. Stelmakhova T.F. Creating sustainable green spaces in conditions of atmospheric pollution and high recreational load. Forestry and agroforestry: Sat. Sciences. Kharkiv : Ukrniilkha, 2000. Issue 112. P. 232-237.

6. Hnativ P.S. Functional diagnostics in dendroecology. Lviv : Kamula, 2014. 336 p.

7. Wyche K.P., Ryan A.C., Hewitt C.N. etc. Emissions of biogenic volatile organic compounds and subsequent photochemical production of secondary organic aerosol in mesocosm studies of temperate and tropical plant species. Atmos. Chem. Phys. 2014. № 14. P. 12781-12801.

8. Harley P., Eller A., Guenther A., Monson R.K. Observations and models of emissions of volatile terpenoid compounds from needles of ponderosa pine trees growing in situ: control by light, temperature and stomatal conductance. Oecologia. 2014. № 176. P. 35-55.

9. Prysedskyi Yu.H. Characteristics of resistance of woody and shrubby plants to air pollution with sulfur, fluorine and nitrogen compound. Bulletin of V. N. Karazin Kharkiv national University. Series: “Biology”. 2014. No. 21. P. 162-167. 